\title{
The Point of the Centre: Present and Past Discourses of "China"-hood
}

\author{
La cuestión del Centro: Discursos \\ presentes y pasados de la Sinitud
}

\author{
David Mervart ${ }^{1}$ \\ University of Heidelberg (Alemania)
}

Recibido: 26-02-16

Aprobado: 04-03-16

\begin{abstract}
With the rise of China over the recent decades, both economic and geopolitical, pundits have increasingly come to remind us that once upon a time what we now call China was the centre of its world. The implication invariably is that just like the historical China was once a centre of global gravity, its current trajectory may be expected to bring today's China inexorably back into the centre of the global order from which it only briefly abstained itself for a few recent centuries.

When making such conjectures, we assume we safely know what China is and where it is. But what is this "China", Zhongguo or Zhonghua, the "Middle Kingdom" or "Central Civilisation", as it is famously called in its native version? It certainly has the claim to centrality in its very name. Yet the name was emphatically not established as a geographic or ethnic label for a territorial state or a nation. Rather, it represented a bold normative claim, a universalist assertion of value. It resembles such lofty epithets as "the Land of the Free", "the new Rome", or "Zion" in that it is above all an aspirational title. Historically, the gravitational pull that has constituted

\footnotetext{
1(david.mervart@uam.es / mervart@asia-europe.uni-heidelberg.de). David Mervart inició sus estudios en la Universidad Carolina de Praga y se especializó en historia del pensamiento político en las universidades de Tokio y Cambridge. Ha sido docente e investigador en el Modern East Asia Research Centre de la Universidad de Leiden y en el Centre for Transcultural Studies de la Universidad de Heidelberg. Actualmente es profesor visitante en la Universidad Autónoma de Madrid. Sus últimas publicaciones son: "Meiji Japan's China Solution to Tokugawa Japan's China Problem". Japan Forum, 27:4 (2015), pp. 544-558. "The Republic of Letters Comes to Nagasaki: Record of a Translator's Struggle". Journal of Transcultural Studies, 2 (2015), pp. 8-37.
} 
what some have called "the Sinosphere" was due to this aspirational universal moral claim more than it was the result of an actual geopolitical hegemony. Until the twentieth century and the arrival on the stage of that brave new invention -the nation- neither territory nor ethnicity really defined "China". A situated view from the neighbourhood may help to clarify this confusing situation. Well embedded in the broader Sinosphere through a complex history of negotiating its relations to the succession of dynastic empires on the mainland, the Japanese archipelago has long been the locus of discussions about the meaning and purpose of the Chinese claim to represent the "Middle Kingdom". Indeed, in terms of statehood and asserted or wished cultural identity, "Japan" has defined itself for most of its history by acknowledging, denying, emulating or arrogating that claim to centrality. We can understand much about what "China" has meant by mapping Japanese aspirations to become China.

Key-words: China, Japan, Sinosphere, politics, Confucianism, nationalism.

\section{Resumen}

El continuo auge económico y geopolítico de China nos recuerda que lo que actualmente se denomina China fue hace un tiempo el Reino del Centro, el centro del mundo. La implicación de esta afirmación es que al igual que la China histórica fue centro gravitacional global en Asia, su trayectoria actual puede reposicionar a China inexorablemente en el centro del orden mundial. El análisis histórico de Zhongguo o Zhonghua, la "Tierra del Medio" o la "Civilización Central", y su postulación a convertirse en referencia moral universal, sin contar con la hegemonía geopolítica real sobre la región circundante, puede arrojar luz sobre este tema. La ambición de China se asemejaba a epítetos como "la Tierra de los hombres libres", "la Nueva Roma" o "Zión". Históricamente, la fuerza gravitacional que constituyó lo que algunos han denominado la sinoesfera procedía de esta postulación moral universal a la cual aspiraba. Dentro de la sinoesfera, en una compleja historia de negociación de relaciones con las sucesivas dinastías imperiales que gobernaban en el continente, Japón ha sido durante tiempo el punto focal de discusión sobre el significado y objetivo de la postulación china de representar el Reino del Centro. Efectivamente, a lo largo de su historia, Japón se ha definido a sí mismo a través del reconocimiento, la negación, la emulación o la demanda de esa centralidad. Quizás podamos entender mejor lo que China ha significado profundizando en las aspiraciones japonesas de ser China.

Palabras-clave: China, Japón, sinoesfera, política, confucianismo, nacionalismo. 
I.

The sudden, supernova-like appearance of the People's Republic of China near the zenith of the starry skies of our century as the second largest economy and a major world power makes it feel like nearly everything about it is new. Its economic miracle, which has happened over the last couple of decades; the skyscraper-filled skyline of its sprawling cities, many of which did not even exist twenty years ago and now house millions of new urbanites who used to be peasants in a backward rural countryside; its society awakening to the full rage of commercialised consumption; its government's new geopolitical assertiveness, which affects not only the increasingly concerned close neighbours, but whole regions far and wide. Yet, the seeming novelty of it all may be deceptive. In many senses -although precisely not in the most expected sense- the current rise of China is better understood as the return to business as usual.

A historian of East Asia is mostly fascinated not by how new these developments are, but how familiar they look from the longue durée perspective. ${ }^{2}$ The queues of western countries' diplomatic and business delegations lining up at the door to secure contracts and advantageous treatment for their trading interests remind us of the centuries during which one western entity after another joined the scramble for Chinese export goods and the privilege of access to the Chinese market. We tend to flag the so-called age of great voyages and discoveries as a hallmark of the dynamism of European history that set off the globalisation whose results we still live with. But the fact is that while the peripheral Europe had for most of its history little produce to offer that might attract overseas merchants, Europeans braved the dangers and misery of high seas primarily in order to reach the centre of economic gravity of the pre-modern world -China-. We all know, although we typically fail to appreciate the significance of the fact, that even the so-called New World was "discovered" as an accidental by-product of an attempt to reach the East Asian markets. The Europeans of the sixteenth, seventeenth and eighteenth centuries risked their life and limb in order not to discover the world but to bring home the prizes that, next to spices, were the most coveted and profitable consumer goods: first silk, then porcelain and later tea. Each of these items followed the same trajectory from rare imported luxury to an indispensable article of the daily life of most Europeans ${ }^{3}$ in much the same way that we now live our

${ }^{2}$ Cf. Philip A. Kuhn, Origins of the Modern Chinese State, Stanford: Stanford University Press, 2002; Alexander Woodside, Lost Modernities: China, Vietnam, Korea, and the Hazards of World History, Cambridge, MA: Harvard University Press, 2006.

${ }^{3}$ Cf. Timothy Brook, Vermeer's Hat: The Seventeenth Century and the Dawn of the Global World, London: Profile Books, 2009; Jan de Vries, The Industrious Revolution: Consumer Behavior and the Household Economy, 1650 to the Present, Cambridge: Cambridge University Press, 2009; Maxine Berg and Helen Clifford, eds., Consumers and Luxury: Consumer Culture in Europe 1650-1850, Manchester: Manchester University Press, 1999. 
lives surrounded inescapably by objects of daily use that are nearly without an exception "made in China".

By the same token, the current ambivalence with regard to the Beijing government sounds like an equally well-rehearsed story. It comprises a peculiar mixture of, on the one hand, envious awe at the sheer magnitude of its accomplishment in keeping a huge territory and population together in relative peace and order and, on the other hand, moral misgivings as to the methods by which such a feat is achieved. In that vein, an infamous head of an EU member state (the current president of the Czech Republic, Miloš Zeman), during his recent official visit to PRC, was reported to have declared he had come to China "to learn how to improve social stability", even while his predecessor in the same office (the former president of the Czech Republic, the late Václav Havel) warned of the lack of respect for basic human and civil rights and the systematic persecution of dissenting opinion in the $\mathrm{PRC}^{4}$. But none of this is a twenty-first or even twentieth-century novelty. Ever since a steady trickle of reports about all aspects of China's society and polity began to arrive in Europe in the seventeenth century, Chinese statecraft has been an object of intense interest that mixed admiration with apprehension and enthusiasm with disdain. ${ }^{5}$

Among the philosophers of the European Enlightenment, Voltaire of course stood out as one of the most outspoken advocates of the China ideal, as the translation of his short text "De la Chine" in the present issue documents. Based on the information that he and his contemporaries drew predominantly from Jesuit missionary reports ${ }^{6}$, he made China to stand for the opposite of almost everything that he criticised about contemporary Europe. It stood for reasonable natural deism as opposed to the superstition and priestcraft that plagued western history; it stood for tolerant enlightenment as opposed to bigoted zealotry; it stood for a government that, absolute in name, was in fact limited by laws and institutions which prevented capricious abuse of power; and it stood for the rule of the scholar-officials, professional administrators selected for their knowledge, as opposed to the rule of hereditary nobility. It may sound peculiar that one could be at the same time an admirer of the English parliamentarism and of the Qing dynasty's imperial state, but in Voltaire's case this had its logic. Both systems were presented as posing different but

\footnotetext{
4 "Nebudu vás poučovat o lidských právech", Lidové Noviny, October 30, 2014, http:// www.lidovky.cz/zeman-do-ciny-se-ucim-jezdit-jak-stabilizovat-spolecnost-pe5-/zpravy-domov. aspx?c=A141030_180244_ln_domov_ele [accessed on 31 January 2016].

${ }^{5}$ Cf. W. W. Davis, "China, the Confucian Ideal, and the European Age of Enlightenment," Journal of the History of Ideas 44 (1983), pp. 523-48; David Martin Jones, The Image of China in Western Social and Political Thought, New York: Palgrave, 2001; Basil Guy, "The French Image of China Before and After Voltaire", Studies on Voltaire and the Eighteenth Century no. 21, Geneva: Libraire E. Droz, 1963.

${ }^{6}$ E.g., Louis Le Comte, Nouveaux memoires sur l'état présent de la Chine, Paris, 1696; Jean Baptiste Du Halde, Description de l'Empire de la Chine, Paris, 1735.
} 
comparably effective institutional curbs on the arbitrary use of power and both seemed conducive to the rise of civilisation in producing peoples free of supersition.

However, both the past and the present understanding of the place and trajectory of China in the world have been based on an assumption that is at least problematic. The assumption is that underneath the mutable face of the numerous and very different polities that have historically occurred on its territory, there is an unchangeable essence of "China"-hood. In his own fashion, Voltaire immortalised this understanding in his play L'Orphelin de la Chine, where a new foreign conqueror of the Middle Kingdom is so awed and humbled by the singular moral uprightness of his conquered Chinese subject that he fully embraces the ways of the former indigenous Chinese rulers, effectively surrendering his foreign identity to become "Chinese". Far from a fanciful fairy-tale, this type of narrative continues alive as an actual historiographical trope where the Mongol or Manchu conqueror dynasties in China are claimed to have fully assimilated and "Sinicised", which wards off any threat of a rupture to the continuity of the "five thousand years of Chinese history". The key difference is between Voltaire's understanding of the essence behind this historical continuity and the understanding proposed by mainstream twentieth century national historiography. To the former, this underlying essence was a system of moeurs, manners, practical morals embodied in the collective life of a society ${ }^{8}$. To the latter, it is a vaguely ethnically and culturally defined nationhood. It is a telling difference that provides us with an important trace to follow over the subsequent pages.

II.

The rise of the People's Republic of China to the status of the world's second biggest economy and to growing geopolitical prominence has attracted enormous attention and generated much discussion worldwide. Yet this economic and geopolitical success has completely overshadowed the magnitude of a completely different but equally astounding achievement of a succession of governments in Beijing. This achievement consists in successfully selling China, or Zhongguo in its native version, both domestically and internationally as a nation and a nation's state, even while both the shape of its current territory and its composition reflect the empire and its expansive colonial conquest that preceded the People's Republic and its allegedly national statehood.

\footnotetext{
7 Voltaire, "L'Orphelin de la Chine", critical edition by Basil Guy, in Haydn Mason, ed., Les auvres complètes de Voltaire, Vol. 45A, Oxford: Voltaire Foundation, 2009.

${ }^{8} \mathrm{Cf}$. Voltaire, "Essai sur les mœurs et l'esprit des nations", critical edition by Bruno Bernard et al., in Haydn Mason, ed., Les œuvres complètes de Voltaire, Vol. 22, Oxford: Voltaire Foundation, 2010. 
This sets today's Chinese state apart from, say, the Habsburg empire, the Ottoman empire, the British empire, or the Romanov empire and its successor the Soviet Union. Albeit all very different from one another and faced with different challenges and crises, all of them decomposed along the vectors of centrifugal forces of mounting calls for national statehood, ethnic, political and religious self-determination, and regional fragmentation. Yet unlike any of them, the empire overseen from Beijing by the Manchu emperor Qianlong at the end of the eighteenth century, at the historical height of its territorial expansion, was nearly the same as the one overseen from Beijing by the cadres of the Chinese Communist Party today. And despite the narrative of officially recognised minorities represented in an ethnically composite Chinese state, the key ideological narrative employed by the current Beijing leadership to legitimate its rule is a straightforward case of good old-fashioned nationalism of the same sort that had once led various German or Slavic peoples to assert their national statehood and independence from the institutional framework of the Habsburg empire. In the eyes of many authors, the People's Republic of China apparently achieved what Benedict Anderson expressed in a memorable metaphor, "stretching the short, tight, skin of a nation over the oversized body of an empire".

This ideological brinkmanship can only work as long as one key assumption is in place, namely, that beneath the superficial plurality of dynastic states and political entities that historically coincided, succeeded or replaced one another on the territory of the contemporary Chinese state, there underlies a deeper unity of a single national past, five thousand years of continuum of Chineseness, Zhongguo-ness, a cultural, ethnic, territorial or some other vaguely undefined identity. This is of course not a peculiarity of the contemporary Chinese state. It is rather, again, a standard tool in the toolbox of all modern nationalisms, shared and mimicked worldwide in a hundred local variations on the same basic theme ${ }^{10}$.

But has this not always been the case? Has not "China" like every other human community always claimed an exclusive distinctive essence and unity that posits a radical difference between "us" on the inside and "them" on the outside, whatever the language in which such a distinction is articulated? The most intriguing lesson from history is precisely that the answer is no, it has not always been the case. For throughout most of its history, "China", at least in its native version of Zhongguo, the "Land of the Middle" or "Middle Kingdom", and Zhonghua, the "Central Flourishing" or "Central Civilisation", was in fact not the name of a territory or a state, still less that of a nation or any such

\footnotetext{
${ }^{9}$ Benedict Anderson, The Imagined Communities: Reflections on the Origin and Spread of Nationalism, London: Verso, 1983, p. 86.

${ }^{10}$ Duara, Prasenjit, Rescuing History from the Nation: Questioning Narratives of Modern China, Chicago: University of Chicago Press, 1997.
} 
purportedly timeless essence. Instead, we could call it an aspirational name. An ambitious symbolic epithet that is not a name tag for a thing or a place, but a claim to embody a normative ideal.

III.

This requires some clarification of the historical background. The terms Zhongguo and Zhonghua emerged early in history and were almost certainly first used to refer to the situation during the first millennium BCE when a plurality of smaller kingdoms scattered over the territory either still deferred to a lose sovereignty of the last of the classical dynasties (the Zhou) or had already launched an open bid to appropriate the sovereignty to themselves. These were the "central states" (for Zhongguo can function as both the singular and the plural) that counted in the geopolitical game for hegemony in the core geographic area that still falls under the territory of the People's Republic of China today. The lands outside of this core, and the peoples that did not enter the game or were regarded as a nuisance, threat, or object of conquest, were designated as barbarian in a practice familiar from other histories ${ }^{11}$.

Out of those centuries of competition, something like a unified imperial state emerged when the Qin state's ruler eliminated the competitors and became the sole sovereign "beneath the heaven" at the end of the third century BCE. But before that happened, in the intense debates that sought to address the geopolitical instability and moral dilemmas that the situation entailed, there emerged a range of formulations of a moral philosophy of statecraft and applied historiography that was offered by itinerant teachers, intellectuals and politico-economic consultants to the rulers and ministers of the many statelets as a guide through the difficult times. In the western parlance, the most influential and durable among these strains of thought came to be known as "Confucianism". But around East Asia, although Master Kong, transcribed by the Jesuit missionaries as Confucius, was always undoubtedly regarded as a central figure in all this, this was never understood as a doctrine promulgated by a single prophet from whom it would take its exclusive name. This was simply "learning". Just like we do not speak primarily of "Platonism" or "Aristotelianism", but rather simply of "philosophy".

${ }^{11}$ Cf. Fairbank, John K., ed., The Chinese World Order: Traditional China's Foreign Relations, Cambridge, MA: Harvard University Press, 1968; Fang Weigui, "Yi, Yang, Xi, Wai and Other Terms: The Transition from 'Barbarian' to 'Foreigner' in Late Imperial China”, in Michael Lackner et al., eds., New Terms for New Ideas: Western Knowledge and Lexical Change in Late Imperial China, Leiden: Brill, 2001. 
Although it had not gone unchallenged, it was in terms of this ("Confucian") moral philosophy and cosmology that the categories of rulership, legitimate sovereignty and desirable shape of the polity came to receive their default definitions. And it was in terms of the same moral philosophy and cosmology that the notion of "China", i.e., Zhongguo or Zhonghua became a universalist statement of principle and a destination to be aspired to, rather than a simple descriptive label for a place or a people.

IV.

To sketch it in grossly simplified terms that gloss over countless disagreements and centuries of heated and divergent discussions and institutional experiments, the normative ideal that "China" as Zhongguo came to stand for could be described as follows ${ }^{12}$. "China" is opposed to the barbarian "others" not because of its national greatness or because of any inherently unique qualities of the land and the people. "China", Zhonghua, is the Central Civilisation because it embodies virtues that are universal in that they correspond to the "Way All Things Need to Be" by their own innermost inclination. These virtues are universal, not culturally specific to a particular people or location, because they define the order of the human world that is an extension or reflection of the natural order of the universe. It is the universal Way for all human relations to be, according to the same inescapable and at the same time benevolent necessity that makes the day break after the night and the four seasons follow one after the other. In the best possible scenario, the sovereign ruler who guards the polity is the ultimate guarantor of this universal order of all human relations. He represents the linchpin between the cosmic order of the universe and the moral order of the human world. Turning north, he faces the heaven and receives the mandate to govern in the name of the same Way following which the stars stick to their fixed trajectories, spring succeeds the winter, parents love their children and sons revere their parents. Because of this pivotal role, the ruler is styled the "Son of Heaven". And the hierarchical order of the human world, with the sovereign ruler at the top, is justified and legitimated by the fact that it embodies these fundamental virtues of benevolence, humaneness, charity, love, care and trust between parents and children, rulers and subjects, kings and ministers. It is of course perfectly possible to transgress against such a basic order of human things, to disregard all these fundamental virtues and behave like a predatory beast, but such a

${ }^{12}$ Cf. Benjamin Schwartz, The World of Thought in Ancient China, Cambridge, MA: Belknap Press, 1985; Anne Cheng, Histoire de la pensée chinoise, Paris: Éditions du Seuil, 1997. 
conduct is ultimately self-destructive, because it undermines the very structures of human sociability, the very possibility of living together like humans and not like animals.

Now, in the harsh empirical reality of the usual business of keeping the human world politically together, tax revenues coming in and the structures of power and privilege in place, such an idealistic formulation of the underlying principles of legitimacy may sound like an ideological whitewash and no doubt it has been used like that more than once in the course of history. But powerful normative ideas are double-edged weapons and can always turn against those who wield them. To legitimate the supreme sovereign's rule in the name of the virtues he is supposed to embody may sound like a cheap way to hold on to the throne. But if fully embraced, this notion at the same time detracts from the untouchable supremacy of the sovereign. After all, the sovereign is only a sovereign for as long as his government upholds and exemplifies the virtues that define the Way things necessarily are. A king or a dynasty may forfeit the mandate to govern, if they are seen to blatantly fail in this basic duty. And having forfeited that mandate, they are no better than armed robbers holding their subjects at the tip of a sword. Such villains receive no protection from the notions of loyalty and reverence due to true kings and justly deserve to be chased away or killed off. This opens door to a justification of a revolution, a removal of the ruler who lost the moral right to rule because he and his ministers failed to uphold the normative virtues of the Way things inevitably are and behaved, or allowed others to behave, like wild predatory beasts.

The number of emperors who suffered violent deaths at the hands of their ministers and subjects throughout Chinese history is in fact considerably high. The contemporary Chinese and Japanese term for "revolution", geming (J: kakumei), is lifted straight from the ancient ("Confucian") classic of Mencius, which justifies the overthrow of corrupt rulers in the name of the "shift of the [heavenly] mandate", geming. And the translation for "republic", gonghe-guo (J: kyōwakoku), comes straight from one of the earliest comprehensive histories, Sima Qian's famous Records of the Grand Scribe, which recorded an episode of the ousting of the oppressive king Li of the Western Zhou (ninth century BCE) and the subsequent period of benevolent kingless rule by virtuous ministers "in unison and harmony", gonghe (J: kyowa ${ }^{13}$. It means that if you wanted to call for the revolution and the establishment of republics in the twentieth century East Asia, you would be doing so in fact in the language of the moral universalism established by the so-called "Confucian" classical learning.

\footnotetext{
${ }^{13}$ Saitō Kowashi, Meiji no kotoba-Bunmei kaika to Nihongo [Meiji words: Progress of civilisation and Japanese language], Tokyo: Kōdansha, (1977) 2005.
} 
IV.

However, if a dynasty may forfeit its mandate, might not even "China", as Zhongguo, lose its "China"-hood? If Zhongguo has been defined as a structure of virtue and humaneness, a civilisational ideal that emanates transformative moral radiation far and wide, what happens if it ceases to be the radiant centre of civilising virtue? Or what happens if another society and polity becomes a more convincing embodiment of such a centre? Does not China, as an empirical historical state and people, in such a case cease to be "China", Zhongguo, the normative ideal of the "Central Civilisation"?

Part of the modern misunderstanding regarding the very concept of "centrality" of the "Central Civilisation" revolves around the criteria of what counts as the centre. As the geopolitical and economic clout of mainland China has continued to grow over the recent decades, pundits have increasingly come to remind us that once upon a time China was the centre of the world, exactly as the native version of its name indicates. The message behind such a reminder is that just as it was once a centre of global gravity, China's current trajectory should be expected to bring it inexorably back centre stage of the global order from which it only briefly abstained itself for a few recent centuries.

When making such conjectures, we assume we safely know what this "China" is and where it can be found. But that may be a problematic assumption. There is no doubt that the strong gravitational pull over close and more distant neigbourhood, a pull that some have come to call the "Sinosphere", was to an extent the function of the sheer size of the empires like those of the Han, Sui or Tang dynasties, their military might, diplomatic weight, and economic strength. But to stand for the "Land of the Middle", Zhongguo, or the "Central Civilisation", Zhonghua, has meant very different things at different points in history and our default criteria of what counts as "the centre" -let us say, a military and economic superpower capable of projecting its influence and protecting its interests worldwide- reflect a very different understanding pertaining to a different era. It is not always easy to conceive what that claim to centrality has historically meant and how it was acknowledged and negotiated by the many bystanders.

During some of the past centuries and millennia, dynastic empires like that of the Han, the Tang or the Qing -the various putative predecessors of the present state that the CPC runs from Beijing-did indeed represent centres of geopolitical and economic power without any serious regional or even global rival. But even during the many centuries when that was not the case, "China", Zhongguo or "Middle Kingdom", did not necessarily lose its central status. That was case, for instance, of the Song dynasty, probably the most geopolitically embattled of the great imperial states of Chinese history. In the 
twelfth century, the Song lost to the northern Jurchen invaders a full half of the former territories north of the Yangzi river, including the capital city Kaifeng and the historical heartland of the Yellow River valley. It continued to hang precariously on to survival in the relatively peripheral south paying a tribute as ransom to the Jurchen Jin dynastic state in the north, until both were overrun by the Mongols ${ }^{14}$. And yet, despite its lackluster geopolitical performance, it continued to represent a key point of cultural reference, a centre of sorts that broadcast some powerful messages into the world around.

It was the squeezed and besieged environment of the southern Song polity that in fact consolidated many of the elements that to the neighbouring region came to stand for the most appreciated Chinese export. This was above all the new systematisation of the so-called "neo-Confucianism" as a comprehensive universal moral, political, and cosmological philosophy and the concomitant practice of a centrally organised state administered by the professional civil service recruited through highly competitive state examinations. Both of these went on to become the staple components of a universally applicable "China"hood. The scholar Zhu Xi, who was active during this time, was what Ibn Rushd, or Averroes, had been to Aristotle. If Confucius was the Philosopher, Zhu Xi became the Commentator. And the grand synthesis of cosmological, moral, and political theory based on ancient classical texts and histories, of which he was the principal author and which reached Korea and Japan, continued to be referred to as "Song learning" (J: Sōgaku), although the dynastic state itself had long disappeared.

Being an economic and military powerhouse was neither the necessary nor the sufficient criterion to qualify as the "Middle Kingdom", Zhongguo, or the "Central Civilisation", Zhonghua. And neither the territory, nor any particular ethnic composition of the population, apparently, would of themselves make one into "China". What did make you into "China", then? When the northern invaders, like the Jurchens, Mongols or the Manchus (all historically called "Tatars" in Europe and "Northern barbarians" in China proper), had completely brought down the existing empires (as happened to the Song or the Ming), overrun the whole of their former territories and established their own dynastic states on the ruins, did that place still continue to be "China", Zhongguo? Or had it become "Barbary" instead? If a conquering tribe fully embraced the universalist premises of "the Middle Kingdom" principle and the new rulers donned the mantle of the virtuous benevolent sage rulers, the way the Manchu emperors did in the seventeenth and eighteenth centuries, had they become as "Chinese" as any of the home-grown dynasties? And if neither the territory nor

14 Barfield, Thomas J. The Perilous Frontier: Nomadic Empires and China, Cambridge, Mass.: Blackwell, 1989; Dabringhaus, Sabine, and Roderich Ptak, eds., China and Her Neighbours: Borders, Visions of the Other, Foreign Policy, 10th to 19th Century, Wiesbaden: Harrasowitz, 1997. 
the ethnicity were its ultimate locus and anchor, was "China" capable of shifting somewhere else altogether? The default ethnic and territorial perspective from which we instinctively organise our world into distinctive continuities and divisions today, the patches of the same colour on the Mercatorian projection of the Earth's surface, is utterly unsuited for understanding what range of meanings "China" as Zhongguo carried.

V.

The question of where "China" is may of course only ever arise when there is a compelling outside point of reference. But the first time it was actually raised was most probably by people whom we would commonsensically designate as "Chinese" inside the territory that we would designate as China. In the fragmented and volatile period of the so-called Six Dynasties after the fall of the Han empire in the third century CE, a thrilling new religion arrived from the south-west. For the early Chinese-speaking adepts of Buddhism the appellation "China", Zhongguo, or the Land of the Middle, was entirely reserved for the centre of the world as they saw it: India, the source of the transformative radiation that brought to them the message that changed their understanding of the human world and of the virtues that supported it. ${ }^{15}$ As the new religion made its successful missionary journey into the heart of the Sui and Tang empires, to the Korean peninsula and on to the Japanese archipelago, its progress was accompanied by the spread of maps of the world that indeed placed the Indian subcontinent squarely in the middle of the known earth ${ }^{16}$. At some point, to some at least, India could have been the true "China". But this was in the very logic of the aspirational nature of the Zhongguo epithet.

It was however the people and polities outside of the boundaries of the actual Chinese empires proper who faced the greatest conceptual difficulty with the normative Zhongguo "China"-hood. Adopting the Chinese script, culture, technology and institutions, the parts of the world that correspond to contemporary Korea, Japan, or Vietnam became integral parts of the extended Sinosphere ${ }^{17}$. That means that they also became party to the debates about

15 Joshua Fogel, "New Thoughts on an Old Controversy: Shina as a Toponym for China", SinoPlatonic Papers 229, 2012, p. 13. Cf. Tian Xiaofei, Visionary Journeys: Travel Writings from Early Medieval and Nineteenth-Century China, Cambridge, MA: Harvard University Asia Center, 2011, p. 97.

${ }^{16}$ Yee, Cordell D. K., "Cartography in China", in John B. Harley and David Woodward, eds., Cartography in the Traditional East and Southeast Asian Societies (The History of Cartography, Vol. II.2), Chicago: The University of Chicago Press, 1994. Cf. Muroga Nobuo and Unno Kazutaka. "The Buddhist World Map in Japan and Its Contact with European Maps", Imago Mundi 16 (1962), pp. 49-69.

17 Joshua Fogel, Articulating the Sinosphere: Sino-Japanese Relations in Space and Time, Cambridge, MA: Harvard University Press, 2009. 
the normative status of the virtues defining "civilisation" and its opposites. Yet however diligently the Korean, Ryūkyūan or Japanese courts replicated the rituals and institutional structures of the mainland Tang or Song models, however much the learned Koreans, Ryūkyūans or Japanese considered themselves full participants in the investigation and practice of the Way things naturally are, the established civilisational geography relegated their polities and their countries of birth and residence to the barbarian fringes of the Chinese empires that continued to describe themselves as the sole "Middle kingdom". The Japanese case is particularly instructive. Therefore, let us dwell on it for a while.

VI.

One solution for coping with the "Central Civilisation" centripetal pull was to establish a genealogical link to it. If the world consisted of a civilised core surrounded on all sides by increasingly barbaric peripheries, then one could try and salvage one's position on the cultural and geographic periphery by claiming that one's own culture was immediately descended from the same sources of that core Central Civilisation. The ancient histories, for example, featured the mythical figure of Taibo (J: Taihaku), the uncle of king Wen from the times of the foundation of the Zhou dynasty, the last pinnacle of the golden classical age, in the eleventh century BCE. Taibo, who was later praised by Master Kong, Confucius himself, as a true sage and a man of "consummate virtue", chose not to press his own legitimate succession claim and rather make room for the smooth transition of rule to his nephew to secure the peaceful and benevolent government for the sake of the whole realm beneath the heaven. He left Zhou, the chronicles claimed, travelled east and went on the sea. This throwaway reference was eagerly seized on in Japan in the later ages. Since such a selfless sage cannot simply disappear from history, was it not perfectly plausible and logical to assume that it was Taihaku (Taibo) himself who founded the dynasty of Yamato rulers of Japan at the dawn of historical time? By the late seventeenth century, many leading intellectuals in Japan (Hayashi Razan, Kumazawa Banzan, Nakae Tōju, or Kinoshita Jun'an) fully subscribed to this idea $^{18}$. Again, this was emphatically not an ethnic or racial claim. The point was not that the Japanese polity was descended from a founding father who was actually "Chinese", but rather that it was descended from one of the ancient (universal, not Chinese) sages and founders of the (universal, not Chinese)

${ }^{18}$ Watanabe Hiroshi, A History of Japanese Political Thought, 1600-1901, transl. D. Noble, Tokyo: International House of Japan, 2012, p. 275; and idem, Kinsei Nihon shakai to Sōgaku [Early Modern Japanese Society and Song Confucianism], Tokyo: Tokyo University Press, 1985, p. 50. 
civilisation. It provided a vital link that sustained the authoritative position of the teaching of the universal Way in a land that would otherwise be left out of the ken of cultured humanity and relegated to the barbarian fringe.

Any contemporary nationalist's instinctive reaction would probably be different. It would be to laugh off the whole idea of "China", Zhongguo or "Middle Kingdom", as self-aggrandising posturing of a neighbouring nation. Even historically, there were some who found the claim to a universal "centrality" of China's "civilisation" a transparent self-serving ploy. Asami Keisai, active at the turn of the eighteenth century, declared that everyone everywhere tended to think of their own country as the middle of the world. The sages of Chinese antiquity and their later followers were no exception. They sought to talk up their own land to make it appear exceptional and unique, like everybody would. But when driven by this local vanity they designated our own land of Japan as eastern Barbary, Keisai claimed, it was a spit in our face that we are not obliged to suffer. For us in Japan, this is our "China", Zhongguo, our "Land of the Middle"19. Despite such assertions, Asami Keisai himself continued to operate very much within the language of the classical "Confucian" learning. But this radical relativism bordered on cynicism regarding any claim to the universal value of virtue. It was hard to reconcile with a continued commitment to the practice of the Way as the pursuit of what was genuinely true and right, not only true and right to us. If anybody was their own "China", Zhongguo, their own "Central Civilisation", by their standards and their own standards alone, did that not undermine the very possibility of any real shared value of humanity? Was anything true and right only to a particular people in their particular time and place?

\section{VII.}

These were hard questions to face and most chose not to go down the path towards which Asami Keisai gestured. Rather, studying "Chinese" classics Mencius or Zhu Xi in Seoul or Edo was not unlike reading Aristotle in Cordoba, Salamanca, Firenze or Prague. In other words, it meant debating universal truths, not engaging with a "Chinese" or "Greek" philosophy, culturally peculiar to ethnic and geographic circumstances of places called Greece and China.

We cannot overemphasise this distinction. Even in Europe, until the onslaught of Romanticism and various national myth-building, none of

${ }^{19}$ Asami Keisai, "Chūgoku-ben” [Distinguishing China], In Nishi Junzō, ed., Nihon shisō taikei 31: Yamazaki Ansai gakuha, Tokyo: Iwanami shoten, 1980, pp. 416-19. Cf. Watanabe Hiroshi, Kinsei Nihon shakai to Sōgaku. 
the many generations of the readers of Plato and Aristotle were particularly concerned about what was happening in Athens during their own lifetimes. Reading Aristotle for normative truths did not entail having some sentimental predilection for "Greece", or the various Venetian or Ottoman provinces that "Greece" had become in its history. In the same way, reading Mencius and Zhu $\mathrm{Xi}$ for the normative truths in Japan or Korea did not necessarily entail being a Sinophile, in the sense of being a friend of the Han people or of whatever dynastic state currently existed on the East Asian mainland. The normative Chūgoku and the empirical China were capable of being kept almost entirely separate. It is only the sort of essentialism that sees culture as a genetic property of an ethnically defined national community that cannot conceive of such a separation.

To a pre-modern observer - unaffected by the default optics of nation states laying their claim on the entire past of their territories- the sequence of the dynastic states did not necessarily compose a continuous history of a single unit called China with its "Chinese" (i.e., "Confucian") culture. These states were different polities, different moral and political formations, long way removed from the classic and post-classic articulations of the normative ideals. And that meant that one could harbour entirely indifferent or outright hostile attitude to any or all of these states and yet be an ardent advocate of the universal normative message that was represented by the shorthand Chügoku (Zhongguo), or Chüka (Zhonghua). For China was not any particular state, let alone an ethnic community with its peculiar (Chinese) culture, or any such other later invention that can stand for a stable essence underneath a flux of transient political formations. As Chūgoku or Chūka, "China" was an aspirational name, a normative claim. Just like, say, "Zion" or "Land of the Free", it was not a geographic or ethnic label.

In 1826, Futagawa Sukechika, a Kyūshū-based scholar, was approached by a friend to write a preface for a Japanese re-translation of a Dutch re-translation of an English translation of a French text by a China-based Jesuit (this was by no means an unusual sort of Chinese whispers going on about pre-modern Eurasia). He agreed and in the preface written in kanbun or classical Chinese as was common for the genre, he exclaimed: "...Why, is this Imperial Land of ours not the real 'China' [Zhongguo, J: Chügoku]?"20.

This was not an accidental use of the term. A good Confucian scholar, Futagawa spoke of China (Zhongguo; Chügoku) of the mythical sage emperors Yao and Shun and the classical Three Dynasties as the undoubted source of the true ritual propriety and the decentralised system of enfeoffed government. He spoke of the decline of this classical Way in China proper as a result of the

\footnotetext{
${ }^{20}$ Abe Ryūhei, Nikoku kaimeiroku [Record of the Conference between the Two States], Manuscript copy from Kyoto University Library (preface dated 1826).
} 
centralising policies of the Qin prince-unifier and the Han dynastic rulers who followed him in fact, while rejecting him in words. He said that it was since this Way was lost and decline set in that China tended to suffer occupation by barbarians (like the Jurchen Jin, Mongol Yuan and Manchu Qing states). Thereupon he listed the contrasting list of virtues that characterised "This Dynasty" (honchō) and "our Imperial Land" (kōkoku): the safety spreading into the fours seas and four corners of the world, the capacity to preserve unadulterated the ancient teachings, complete with the proper rituals and ceremonies; the same decentralised enfeoffed government that had once characterised the pre-Han China of the classical times of Confucius. It was as a result of this contrastive comparison that he went on to declare: Is it not really Japan where "China" resides now? ${ }^{21}$.

Futagawa was definitely not alone or eccentric in arguing this way. Just a year earlier, in 1825, Aizawa Seishisai, a retainer of the Tokugawa domain of Mito, wrote a treatise called Shinron or "New Theses". He wrote it in kanbun or classical Chinese, the common register for educated high-status prose. This treatise went on to become effectively the bible to the subsequent generation of enthusiastic young men with a sense of mission. Amid the twin internal and external crises of the 1850s, these young men found in the (Chinese) text of Aizawa Seishisai's New Theses a powerful articulation of what they saw as their sacred duty to uphold the loyalty to an image of a unified Japan and its mythical imperial dynasty descended in an unbroken lineage from a deity at the beginning of time. Seeing something as one's sacred duty is usually not conducive to a pragmatic readiness to reach political compromise. Many of the enthusiastic young readers of the New Theses turned into extremists and assassins targeting both the western foreigners, whom they regarded as sneaky barbarians, and members of the domestic establishment, whom they regarded as traitors and collaborators. Daring terrorist attacks and suicidal assassination attempts were their favourite strategy. This made many parts of Japan of the 1850s and 1860s into a very volatile and dangerous place, something along the lines of Afghanistan in our days. And yet it was from the ranks of these young extremist readers of the New Theses that the future leaders of the Meiji Japan were recruited. They went on to become government ministers and foremost dignitaries of a restored imperial state and embarked on the project of constructing a nation with a mystic divine aura attached to it, a strategy they saw as the best blueprint for survival in the rough new world of inter-state competition. Aizawa Seishisai's New Theses were effectively a proto-nationalist manifesto that provided the ideological springboard for many of these developments ${ }^{22}$.

\footnotetext{
21 Ibid.

22 Bob Tadashi Wakabayashi, Anti-Foreignism and Western Learning: Aizawa Seishisai's New Theses, Cambridge, MA: Harvard University Asia Center, 1986.
} 
It may therefore come as a surprise to discover that whenever Aizawa Seishisai writes "China", Chügoku, Zhongguo, what he mean is in fact Japan. Or rather, he means the ideal unified imperial Japan towards which he evokes the sacred duty of uncompromising and unconditional loyalty. When he needs to refer to the big state across the sea on the mainland, he calls it as it mostly called itself, by its dynastic name, i.e., the Ming or the Qing. And when he does need a generic toponym beyond the particular polities on the mainland, he very intentionally resorts to one of the much less lofty designations that were in currency at the time: Seido (Western land), Tōdo or Tözan (Tang-land or Tangmountains, where the name of the Tang dynasty had become a synecdoche for China as a whole), Kara or Morokoshi (Japanese readings of the Chinese character Tang), or from a different direction, Shina, to echo the European toponym China that we still use and that is derived from Sanskrit ${ }^{23}$.

It may strike us as puzzling and counterintuitive that the founders of Japanese nationalism should formulate their ideology in classical Chinese and that by way of doing so they should insist on calling their own land "China". But exactly that was the case. Yet again, there should be nothing puzzling about the fact that an early nineteenth-century Japanese proto-nationalist and loyalist extremist could call Japan Chügoku, "China". It only appears puzzling if we allow the modern mind's inertia to essentialise "China" into an ethno-cultural unit that provides a natural continuity underlying a plurality of dynastic states, the "five thousand years of Chinese history".

If only "China", Zhongguo, is understood for what it was commonly understood to be, that is, neither a territory nor a nation, but a universal normative aspiration -really more akin to such later concepts as "civilisation" and "modernity"- then this rhetorical move makes perfect sense. The movement that culminated in the installing of a new centralised state in Japan in the name of a reinvented loyalism to a resurrected eternal imperial dynasty was a movement that took its cue from authors who insisted on Japan being "China". True, a backlash against the foreign "Chinese intellectualism" in the name of pure and uncorrupted indigenous Japanese essence had just been launched by the so-called "nativist studies" of the likes of Motoori Norinaga $(1730-1801)^{24}$, but it was the very novelty of this attack that confirmed the universalist understanding of classical China as the default position.

In the end, the politically active proto-nationalism took probably less from the sentimental cultural essentialism of a Motoori Norinaga -who was prone to blame all the evils of his world on the "Chinese" calculating mindset imported

\footnotetext{
${ }^{23}$ Joshua Fogel, "New Thoughts on an Old Controversy: Shina as a Toponym for China", SinoPlatonic Papers 229, August 2012.

${ }^{24}$ Watanabe Hiroshi, "A Peculiarly 'Pure Heart': The Thought of Motoori Norinaga", A History of Japanese Political Thought, 1600-1901, trans. David Noble, Tokyo: International House of Japan, 2012, pp. 238-252.
}

Araucaria. Revista Iberoamericana de Filosofía, Política y Humanidades, año 18, n 35. Primer semestre de 2016. Pp. 127-150. ISSN 1575-6823 e-ISSN 2340-2199 doi: 10.12795/araucaria.2016.i35.07 
from the mainland- than from theorists like Aizawa Seishisai, whose claim for Japan's exceptionality was that it was better at being China than any of the latter-day false pretenders to "China"-hood on the mainland. This meant, among other things, that Confucius, Mencius, or Zhu Xi belonged more to Japan's own lineage than to any of the dynastic empires on the continent that we are accustomed to calling "Chinese". Had things stayed that way, Confucius Institute could have been the name for Japanese state's own soft power cultural centre today.

\section{VIII.}

The story, however, does not end there. The modern Japanese state, which resulted from the 1868 loyalist Meiji revolution that took its cue from the exhortations of Aizawa Seishisai, in the event did not insist on calling itself "China". The new state plunged straight into a global world of high imperialism and the concomitant scramble for overseas colonial territories and markets, a world that had no plausible moral center point and the aspiration to create and sustain one seemed a stretch, at least for the time being. The postrevolutionary Meiji Japan in the latter half of the nineteenth century embarked with great urgency on the twin project of building a strong, centralised state that could withstand the economic and military competition on the international stage, and manufacturing a unified nation, a people joined by the sense of common purpose and spontaneous, emotive belonging together from the past immemorial ${ }^{25}$. Aizawa Seishisai and his followers had seen both of these projects as indispensable for the creation and sustaining of a national polity of the kind they called for. But it was the latter of them, the creation of a nation, the "unity of hearts and minds of the thousands and millions", that they saw as a precondition for the former, the construction of a strong state. In 1825, when Aizawa Seishisai penned his manifesto, there existed no nation in the Japan of the Tokugawa shoguns, nor in the China under the Manchu Qing dynasty ${ }^{26}$. He was convinced that it was the unity of hearts and minds, the magnificent mobilising power of the national ideology, rather than any technological supremacy, what gave the western powers their remarkable advantage in conquering the globe and dictating their conditions ${ }^{27}$.

\footnotetext{
${ }^{25}$ Carol Gluck, Japan's Modern Myths: Ideology in the Late Meiji Period, Princeton: Princeton University Press, 1985.

${ }^{26}$ Joshua Fogel, ed., Teleology of the Modern Nation State: China and Japan, Philadelphia: University of Pennsylvania Press, 2005.

${ }^{27}$ Bob Tadashi Wakabayashi, Anti-Foreignism and Western Learning in Early Modern Japan: Aizawa Seishisai’s New Theses, Cambridge, MA: Harvard University Asia Center, 1986.
} 
It was invariably through Japan that the ideas of nation or race, as well as constitutionalism, civil rights or parliamentary government, anarchism or communism, reached Chinese audiences ${ }^{28}$. And it was through neologisms coined in Japanese translations that the conceptual vocabulary pertaining to all these novelties entered modern Chinese ${ }^{29}$. Nationalism was part of the toolbox of a global modernity that spread around in the nineteenth century by means of texts, translations, personal reports and hearsay, via a network of readers, travellers, migrants, political refugees and other brokers moving among cities on the crossroads of worldwide traffic in goods, people and ideas. In the years around the turn of the twentieth century, a flood of Chinese visitors, students, government officials and exiled activists arrived at Japanese shores seeking a recipe for fixing the broken Qing polity. Among them were some of the most influential voices of the country rapidly transforming from a failed empire into a new type of state based on freeing the "Chinese nation" from the "foreign" Manchu conquest. The foremost reformists Kang Youwei or Liang Qichao, as well as the father founder and future first president of the new Republic of China, Sun Yat-sen, all spent time in exile in Yokohama and Tokyo and had close and formative ties to the Japanese intellectual and political circles ${ }^{30}$.

The vertiginous circuit thus slowly closed at last. The universalist ideas of the so-called Confucian statecraft, which had long served as the discursive base and default legitimation to a succession of empires on the Asian mainland, and which posited a center of moral gravity and transformative culture -the "Middle Kingdom" or "Central Civilisation"- came in handy in a Japan where many looked for a solution for the constitution of a national polity in face of the crises brought by the mid-nineteenth century. The "moral transformation" trope -in place for some two millennia to explain the effects of the ideal governance in accord with the universal heavenly mandate- was recast in Japan in the 1820 s through the 1860 s as the imperative transformation of the disjointed individuals, groups and regions into a single cohesive body of a nation, a sort of national civil religion. The Confucian universalist language was inconspicuously converted to a particularist ideology of nation building. The marvelous success of the project in Japan was quickly noted and appreciated among the concerned Chinese in the last days of the Qing empire. And by the

\footnotetext{
${ }^{28}$ Satō Shin'ichi, Kindai Chūgoku chishikijin to bunmei [Modern Chinese Intellectuals and Civilisation], Tokyo: Tokyo University Press, 1996, p. 316-17.

${ }^{29}$ Saitō Kowashi, Meiji no kotoba-Bunmei kaika to Nihongo [Meiji words: Progress of civilisation and Japanese language], Tokyo: Kōdansha, (1977) 2005; Michael Lackner et al., eds., New Terms for New Ideas: Western Knowledge and Lexical Change in Late Imperial China, Leiden: Brill, 2001; Joshua Fogel, ed. and trans., The Emergence of the Modern Sino-Japanese Lexicon: Seven Studies, Boston, Leiden: Brill, 2015.

${ }^{30}$ Marius B. Jansen, The Japanese and Sun Yat-Sen, Cambridge, MA: Harvard University Press, 1954; Hsiao Kung-Chuan, A Modern China and a New World: K'ang Yu-wei, Utopian and Reformer, 1858-1927, Seattle: University of Washington Press, 1975.
} 
opening of the twentieth century, the necessity of manufacturing a nation was on the top of the agenda of the Chinese reformers and activists ${ }^{31}$.

\section{IX.}

All that busy stream of multipolar borrowings, transmissions, appropriations and recyclings appeared to come to an abrupt end with the victory of the Chinese Communist Party in the civil war and the establishment of the People's Republic of China in 1948. Like everywhere else, the new communist state loudly announced itself as a radical, almost millennial rupture with all the things past. Prominent among the feudal relics to be extirpated from the present lives and from the memory of the citizenry was the Confucian ideology that had allegedly kept the labouring classes in subjection and hindered China's progress. The old world of a moral universalism shared across national boundaries seemed to meet its definitive demise. But did it?

The Beijing politburo and the cadres of the party, strengthening their hold over not just the present but also the past of the country, are currently busy recasting the universalist aspiration to normative "China"-hood as a nation's history and a national cultural heritage ${ }^{32}$. This serves both to appropriate its historical authority as an additional source of legitimacy and to neutralise its potential as a critical intellectual force. "Confucius Institute" is now the name for the network of cultural centers projecting PRC soft power abroad. A vast bronze statue of Master Kong, or Confucius was erected in 2011 outside of the National Museum fronting the famous Tiananmen Square in Beijing, to join the complete lineup of the communist party's nationally promulgated icons. Before it was moved to a less prominent location some months later, Master Kong thus came literally face to face with Chairman Mao, who had in the 1960s instigated a movement to root out everything that was still remotely reminiscent of the old habits of mind, including the feudal notions of "Confucianism". The posthumous encounter of the two was in fact probably less an unintended irony and more an intentional act of reconciliation as both are now fully expected to harmoniously inhabit the same national pantheon. Like in the days of the Qing emperors, Master Kong's birthday is once again the object of official recognition. Last year, president $\mathrm{Xi}$ Jinping gave a high-profile keynote

31 Cf. Michael Lackner, "Anmerkungen zur historischen Semantik von China, Nation, und chinesischer Nation im Modernen Chinesisch", in Horst Turk et al., eds., Kulturelle Grenzziehungen im Spiegel der Literaturen: Nationalismus, Regionalismus und Fundamentalismus, Göttingen: Wallenstein Verlag, 1998.

32 Cf. the contribution by Taciana Fisac, "Revolución, política y propaganda en la China contemporánea" in this issue and idem, "Discursos del poder en la China contemporánea", Revista de Occidente, No. 414 (November 2015), pp. 20-36. 
speech at an international symposium in Beijing commemorating the 2565th anniversary of the sage's birth in which he stated that the thought associated with Confucius's name represents a record "of spiritual experiences, rational thinking and cultural achievements of the nation while it strived to build its identity" and added that its cultural heritage has "nourished the flourishing Chinese nation" 33 .

Both the universalist moral aspiration of the learning from the ancient sages and the panoply of disparate non-national polities that preceded the People's Republic of China have thus been repackaged as the cultural heritage of the state and the state's nation that extends its dominion over the entire past of its territory. It seems such a natural state of affairs that it is difficult to imagine how it could ever be otherwise. A peek at the history of the importance of being the universal "China" may help to keep us sensitive to the fact that many other possibilities have always existed. And considering how heavily the nationalised histories all around East Asia weigh on today's mutual relations among the polities in the region, there is something mildly optimistic in the realisation that the seemingly inexorable grip of national narratives over the totality of the past is a relatively recently descended smoke screen. Perhaps it is not here forever.

${ }^{33} \mathrm{Mu}$ Xuequan, "China commemorates Confucius with high-profile ceremony", Xinhuanet, 25 September, 2014. (http://news.xinhuanet.com/english/china/2014-09/25/c_127030072.htm) [accessed on 31 January, 2016]. 


\section{Bibliography:}

Abe Ryūhei, Nikoku kaimeiroku [Record of the Conference between the Two States], Manuscript copy from Kyoto University Library (preface dated 1826).

Anderson, Benedict, The Imagined Communities: Reflections on the Origin and Spread of Nationalism, London: Verso, (1983) 1991.

Asami Keisai, "Chūgoku-ben" [Distinguishing China], in Nishi Junzō, ed., Nihon shisō taikei 31: Yamazaki Ansai gakuha, Tokyo: Iwanami shoten, 1980.

Barfield, Thomas J., The Perilous Frontier: Nomadic Empires and China, Cambridge, MA: Blackwell, 1989.

Benjamin A. Elman, J. B. Duncan and H. Ooms, eds., Rethinking Confucianism: Past and Present in China, Japan, Korea and Vietnam, Los Angeles: UCLA Asia Pacific Monograph Series, 2002.

Berg, Maxine and Helen Clifford, eds., Consumers and Luxury : Consumer Culture in Europe 1650-1850, Manchester: Manchester University Press, 1999.

Brook, Timothy, Vermeer's Hat: The Seventeenth Century and the Dawn of the Global World, London: Profile Books, 2009.

Chou Kai-Wing, Kevin M. Doak, and Fu Poshek, eds., Constructing Nationhood in Modern East Asia, Ann Arbor: University of Michigan Press, 2001.

Dabringhaus, Sabine, and Roderich Ptak, eds., China and Her Neighbours: Borders, Visions of the Other, Foreign Policy, 10th to 19th Century, Wiesbaden: Harrasowitz, 1997.

Duara, Prasenjit, Rescuing History from the Nation: Questioning Narratives of Modern China, Chicago: University of Chicago Press, 1997.

Fairbank, John K., ed., The Chinese World Order: Traditional China's Foreign Relations, Cambridge, MA: Harvard University Press, 1968.

Fang Weigui, "Yi, Yang, Xi, Wai and Other Terms: The Transition from 'Barbarian' to 'Foreigner' in Late Imperial China", in Michael Lackner et al., eds., New Terms for New Ideas: Western Knowledge and Lexical Change in Late Imperial China, Leiden: Brill, 2001.

Fisac, Taciana, "Discursos del poder en la China contemporánea", Revista de Occidente, No. 414 (November 2015), pp. 20-36.

Fogel, Joshua, Articulating the Sinosphere: Sino-Japanese Relations in Space and Time, Cambridge, MA: Harvard University Press, 2009.

, "New Thoughts on an Old Controversy: Shina as a Toponym for China", Sino-Platonic Papers 229, August 2012.

Fogel, Joshua, ed. Teleology of the Modern Nation State: China and Japan, Philadelphia: University of Pennsylvania Press, 2005. 
Fogel, Joshua, ed. and trans., The Emergence of the Modern Sino-Japanese Lexicon: Seven Studies, Boston, Leiden: Brill, 2015.

Gladney, Dru C., Dislocating China: Reflections on Muslims, Minorities and Other Subaltern Subjects, London: C. Hurst \& co., 2004.

Gluck, Carol, Japan's Modern Myths: Ideology in the Late Meiji Period, Princeton: Princeton University Press, 1985.

Howland, Douglas, Borders of Chinese Civilization: Geography and History at Empire's End, Durham: Duke University Press, 1996.

Hsiao, Kung-Chuan, A Modern China and a New World: K'ang Yu-wei, Utopian and Reformer, 1858-1927, Seattle: University of Washington Press, 1975.

Jansen, Marius B., The Japanese and Sun Yat-Sen, Cambridge, MA: Harvard University Press, 1954.

Jones, David Martin, The Image of China in Western Social and Political Thought, New York: Palgrave, 2001.

Kuhn, Philip A., Origins of the Modern Chinese State, Stanford: Stanford University Press, 2002.

Lackner, Michael, "Anmerkungen zur historischen Semantik von China, Nation, und chinesischer Nation im Modernen Chinesisch", in Horst Turk et al., eds., Kulturelle Grenzziehungen im Spiegel der Literaturen: Nationalismus, Regionalismus und Fundamentalismus, Göttingen: Wallenstein Verlag, 1998.

Lackner, Michael et al., eds., New Terms for New Ideas: Western Knowledge and Lexical Change in Late Imperial China, Leiden: Brill, 2001.

Laufer, Berthold, "The Name China”, T'oung Pao 83:4-5 (1912), pp. 719-726. Levenson, Joseph R., "T'ien-hsia and Kuo and the 'Transvaluation of Values", Far Eastern Quarterly 11:4 (1952), pp. 447-451.

Muroga Nobuo and Unno Kazutaka, "The Buddhist World Map in Japan and Its Contact with European Maps", Imago Mundi 16 (1962), pp. 49-69.

Saitō Kowashi, Meiji no kotoba-Bunmei kaika to Nihongo [Meiji words: Progress of civilisation and Japanese language], Tokyo: Kōdansha, (1977) 2005.

Satō Shin'ichi, Kindai Chūgoku chishikijin to bunmei [Modern Chinese Intellectuals and Civilisation], Tokyo: Tokyo University Press, 1996.

Schwartz, Benjamin, The World of Thought in Ancient China, Cambridge, MA: Belknap Press, 1985.

Tian Xiaofei, Visionary Journeys: Travel Writings from Early Medieval and Nineteenth-Century China, Cambridge, MA: Harvard University Asia Center, 2011.

Toby, Ronald, "Contesting the Centre: International Sources of Japanese National Identity", International History Review 7:3 (1985), pp. 347-363. de Vries, Jan, The Industrious Revolution: Consumer Behavior and the 
Household Economy, 1650 to the Present, Cambridge: Cambridge University Press, 2009.

Wakabayashi, Bob Tadashi, Anti-Foreignism and Western Learning in Early Modern Japan: Aizawa Seishisai's New Theses, Cambridge, MA: Harvard University Asia Center, 1986.

Watanabe, Hiroshi, Kinsei Nihon shakai to Sōgaku [Early Modern Japanese Society and Song Confucianism], Tokyo: University of Tokyo Press, 1985. , A History of Japanese Political Thought, 1600-1901, trans.,

David Noble, Tokyo: International House of Japan, 2012. ," "They Are Almost the Same as the Ancient Three Dynasties':

The West as Seen through Confucian Eyes in Nineteenth-Century Japan", in Tu Wei-ming, ed., Confucian Traditions in East Asian Modernity: Moral Education and Economic Culture in Japan and the Four Mini-Dragons, Cambridge, MA: Harvard University Press, 1996.

Wildman-Nakai, Kate, "The Naturalization of Confucianism in Tokugawa Japan: The Problem of Sinocentrism", Harvard Journal of Asiatic Studies 40:1, 1980.

Woodside, Alexander, Lost Modernities: China, Vietnam, Korea, and the Hazards of World History, Cambridge, MA: Harvard University Press, 2006.

Yee, Cordell D. K., "Cartography in China", in John B. Harley and David Woodward, eds., Cartography in the Traditional East and Southeast Asian Societies (The History of Cartography, Vol. II.2), Chicago: The University of Chicago Press, 1994. 